\title{
ANALYSIS OF ELASTICITY AND BUOYANCY AND PROJECTION OF TAX IN NEPAL
}

\author{
Dil Nath Dangal
}

\begin{abstract}
This study has been designed to calculate elasticity and buoyancy and projection of various taxes in Nepal from 2018 to 2020. This study is based on secondary data published by the government of Nepal covering a period between the fiscal year 2000 to 2016. The various sources of revenue as a proportion of the Gross Domestic Product (GDP) have been analyzed during this period. This study particularly deals with the analysis of elasticity and buoyancy of tax and nontax revenue. The projection of tax revenue since 2018 to 2020 has also been forecasted. The findings reveals that the overall tax system of Nepal seemed to be inelastic during study period, and direct taxes appeared smaller elasticities than indirect taxes and that buoyancy coefficients of major taxes became much higher than their respective elasticities.
\end{abstract}

Key words: Elasticity, buoyancy, VAT, income tax, custom duty, excise duty, registration fee, vehicle tax, and GDP.

\section{INTRODUCTION AND OBJECTIVE}

Tax elasticity and buoyancy measure the responsiveness of tax revenues to changes in the GDP. Elasticity and buoyancy are two popular concepts, mostly used to measure the responsiveness of taxes in a tax system. These concepts help to explain the overall structure of a tax system and serve as valuable analytical tools for designing tax policy.

Every country undertakes revenue projections in the process of formulating its budget. When the revenues seem smaller than the budget expenditures, countries end up in deficit financing. Because underdeveloped countries have few possibilities for prolonged external financing of budget deficits, without causing too much disturbance in the macroeconomic environment, each country must decide how best to increase its internal tax revenues to meet its expenditure needs. One way that countries raise additional revenue is through discretionary tax measure. The best outcome expected from such changes is that the tax system will automatically yield

* Dr. Dangal is a Lecturer, Ratna Rajya Campus, Bhrikuti Mandap, Kathmandu, TU. 
corresponding tax revenues as income or GDP grows, on a sustainable basis. The objectives of this study were (i) to calculate elasticity and buoyancy, and (ii) project various taxes of Nepal from 2018 to 2020.

\section{REVIEW OF LITERATURE}

The concepts of elasticity and buoyancy of taxes are often used in measuring the responsiveness of tax collection with respect to change in GDP or GNP. A high elastic tax system is said to be desirable; in most of the cases, the major sources of government revenue may have low elasticity in which cases, however, the authorities must seek additional revenue by introducing discretionary changes. Then, the growth in tax revenue may come about through high buoyancy as opposed to the natural growth through elasticity (Mansfield, 1972).

The given tax system is said to be elastic if elasticity coefficient exceeds unity; otherwise, it is considered as inelastic. To bridge the resource gap in any economy, an elastic tax system is highly advantageous because it reduces the probable instability in the economy due to change in tax rates or its legal base (Rana, 2008). In a developing economy where the tax system has to be used as an important source of financing development, there is a need for making the various taxes income elastic. The taxes must be devised in such a manner that a large part of the increment in national income flows into the exchequer automatically. This way avoids the necessity for making frequent changes in the tax rates or the tax base. There are many political and administrative difficulties in securing additional revenue by often altering the tax rates or tax base. Moreover, these difficulties will create uncertainty in the tax structure that is not conducive to economic growth (Sahota, 1961).

Tax elasticity and tax buoyancy measure the response of tax revenues to changes in the GDP. These concepts help to explain the overall structure of a tax system and serve as valuable analytical tools for designing tax policy. Elasticity and buoyancy are two popular concepts, mostly used to measure the responsiveness of taxes in a tax system. The term elasticity is also called Built-in-flexibility or Stabilized coefficient, in which elasticity measures the automatic response of tax to the change in national income, but buoyancy includes discretionary changes and revenue through administrative efforts. The term Buoyancy is also known as sensitivity or exploitation coefficient or formula flexibility. Elasticity provides the basis for natural growth of revenue to GDP without any change 
in structure or base of tax. But buoyancy provides what actually happens in the economy in which normal growth of revenue, discretionary changes, and the revenue through administrative efforts are included. Elasticity is a static concept whereas buoyancy is a dynamic one. Revenue productivity has been considered as the function of elasticity and buoyancy. The higher the buoyancy and elasticity coefficients, the more efficient will be particular tax system (Dahal, 1983).

Resource mobilization has a crucial role in fiscal policy implementation, especially in a developing country where the demand of public funds is high for public expenditure. The demand for public funds is the better source of resource mobilization than other sources, such as deficit financing and money creation. Became tax revenue is the major source of domestic revenue in Nepal, the measurement of tax elasticity and buoyancy would be very beneficial in terms of reforms in tax structure as well as revenue administration. In addition, the study of tax elasticity and buoyancy is also useful for revenue forecasting (Gautam, 2008).

All in all, a distinction is generally made between elasticity and buoyancy of a tax or the tax system as a whole. Elasticity or Built-inflexibility refers to the automatic responsiveness of the tax revenue to changes in national income and any change in the other factors influencing the tax revenue and buoyancy means the responsiveness of the tax revenue to changes in national income, taking also into account the change in the tax revenue due to all the other factors which influence it.

In Nepal's tax structure, various researchers have found heterogeneous responsiveness of taxes to GDP in the periods of 1952/53 to $198 / 82$ (Dahal,1983). In this period, the overall elasticity of the total revenue equaled almost unity (1.01); for indirect tax, it became marginally higher than unity (1.02) compared with the elasticity of direct tax (0.68); and the elasticity of tax revenue was found to be 0.92 , reflecting that the tax system was less responsive to change in income. But the buoyancy coefficients for the same period seemed 1.54 for total revenue, 1.52 for tax revenue, 1.63 for indirect taxes and 1.23 for direct taxes.

Regarding the buoyancy and elasticity of different taxes for the study period among the individual taxes, Rana (2008) found that, , the elasticity of sales tax become the highest (1.96), followed by income tax (1.38), import duties (1.05), export duties (0.77), and land tax (-0.04). The buoyancy coefficient for sales tax appeared again highest (2.56), followed 
by excise duties (2.23), income tax (1.86), import duties (1.79), export duties (1.14), and land tax (0.31). These figures imply that the inelasticity of taxes in the tax structure of Nepal was observed to be concentrated primarily on land tax, export duty, import duty, excise duty and, to some extent, on income tax.

Agrawal (1998) found that the buoyancy and elasticity of income tax for the period $1967 / 68$ to $1975 / 76$ was 2.18 and 2.0, respectively, implying that income tax looked promising future prospects (Reejal, 1976). But the elasticity of the land tax become the lowest (0.12) and the buoyancy coefficient (0.17), although sales tax (1.74) and excise duties (1.29) seemed fairly elastic. In terms of buoyancy coefficient, excise tax (2.20) secured the first position followed by sales tax (2.20) and income tax (2.18).

Reejal (1976 cited in Dahal, 1983 \& Agrawal, 1998) covered the period from $1964 / 65$ to $1970 / 71$. This study has indicated that Nepal's tax structure as a whole seemed fairly elastic, with elasticity coefficient 1.82 and buoyancy 2.18 for the total tax revenue. In this study, income tax seemed to be highly progressive with elasticity coefficient 4.39 , the highest among all the tax categories. For this, Reejal pointed out that it was due to exemption effect and rate effect. As between direct and indirect taxes, the elasticity coefficient of the former (2.25) appeared bigger than that of the latter (1.52), indicating that direct tax as a whole seemed more progressive than indirect tax as a whole.

Dhungana (1980) dealt with the productivity of the Nepalese tax structure in his study. His study covered the main components of indirect taxation that is, excise, sales and customs - and found that the elasticity coefficient for total tax revenue was reported to be 1.24 and buoyancy coefficient to be 1.73 , indicating that the Nepalese tax system appears fairly progressive.

\section{METHODOLOGY}

This article is based on the descriptive method of analysis. This study has used 15 years of secondary data for analysis purpose. The required data were taken from Economic Survey of Ministry of Finance, an unpublished thesis, books, and magazines. The data were analyzed by using chart and trend lines. The buoyancy and elasticity could be calculated as: 
Tax buoyancy $(\mathrm{TB})=\% \Delta$ Revenue $\div \% \Delta$ Base

Where $\mathrm{TB}=$ Tax buoyancy

$\Delta \quad=\quad$ change

Revenue $\quad=\quad$ Total revenue

Base $=$ Typically GDP

And, Tax elasticity (TE) $=\% \Delta$ Revenue $\div \% \Delta$ Base

These two formulas are the same but a crucial difference lies in the assumption by which revenue is calculated had there not been any changes in tax laws, rates or bases. Therefore, it is hypothetical. It is useful to identify which taxes are naturally elastic. Tax yields more revenue as GDP rises, even if the rates are not changed.

\section{ANALYSIS}

Elasticity indicates what magnitude of a tax would have been over the period of time when there would be no change in the tax rates and the legal base. It is a static concept of the measurement of responsiveness of the taxes in a tax system. An elasticity of unity (i.e.,1) in a tax system would imply one percent change in GDP would be accompanied by one percent change in tax revenue. An elasticity greater than unity implies that the percentage change in tax revenue will be more than the percentage change in GDP. An elasticity less than unity implies that the percentage change in tax revenue will be less than the percentage change in gross domestic product, and the tax is said to be inelastic. An elastic tax structure is hoped in any economy because it is highly advantageous for public expenditure activities. An elastic tax structure helps to strike a balance between equity, growth, and efficiency for an economy.

On the other hand, the buoyancy of a tax system is a summary indication of the historical responsiveness of tax collections to the growth in GDP. The buoyancy measure provides a floating value (or face value) of the taxes in a tax system. The buoyancy includes both automatic growth and the discretionary changes. It reflects the influence of such factors as sensitivity of the tax base to the growth in national income, the progressivism of the rate structure, the nature and frequency of discretionary actions, and the change in prices. Thus, it can be viewed as a total account of the tax responsiveness to the changes in the national income. A tax system is not necessarily automatic responsive or elastic in nature. 
To make the system more responsive, therefore government effort is needed in the form of additional taxation and the improved administrative competences. These governmental efforts are called discretionary measures and could be seen from buoyancy estimates of a tax system. The buoyancy coefficient of a tax system is given by the ratio of percentage change in the tax revenue to the percentage change in national income. The buoyancy of a tax system gives an idea about the overall increase including the effects of both automatic increase and the increase due to the discretionary changes (Chapagain, 2003).

Table 1: Different Tax Heads of 2000 to 2015

(Rs in crores)

\begin{tabular}{|c|c|c|c|c|c|c|c|c|c|c|}
\hline $\begin{array}{c}\text { Fiscal } \\
\text { year }\end{array}$ & ثิ & 늘 & 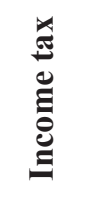 & 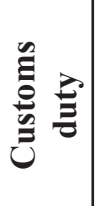 & $\sum_{2}^{E}$ & 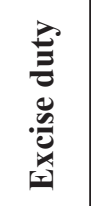 & 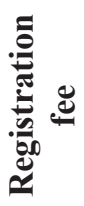 & 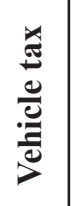 & 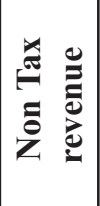 & 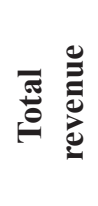 \\
\hline 2000 & 37949 & 3293 & 772 & 1081 & 1026 & 313 & 102 & 22 & 974 & 4267 \\
\hline 2001 & 44152 & 3844 & 912 & 1255 & 1238 & 377 & 61 & 43 & 1002 & 4846 \\
\hline 2002 & 45944 & 3932 & 891 & 1265 & 1227 & 381 & 113 & 56 & 1111 & 5043 \\
\hline 2003 & 49220 & 4351 & 984 & 1423 & 1346 & 478 & 61 & 43 & 1364 & 5715 \\
\hline 2004 & 53680 & 4843 & 951 & 1555 & 1448 & 623 & 170 & 70 & 1415 & 6258 \\
\hline 2005 & 58910 & 5442 & 1047 & 1570 & 1889 & 645 & 180 & 81 & 1601 & 7043 \\
\hline 2006 & 65410 & 5799 & 1094 & 1534 & 2161 & 651 & 218 & 85 & 1485 & 7284 \\
\hline 2007 & 72780 & 7182 & 1573 & 1671 & 2610 & 934 & 225 & 100 & 1658 & 8840 \\
\hline 2008 & 81570 & 8687 & 1908 & 2106 & 2982 & 1119 & 294 & 107 & 2246 & 10933 \\
\hline 2009 & 98830 & 11917 & 2725 & 2679 & 3972 & 1622 & 522 & 185 & 2642 & 14559 \\
\hline 2010 & 119280 & 15900 & 3382 & 3515 & 5509 & 2431 & 551 & 242 & 2365 & 18265 \\
\hline 2011 & 137500 & 17616 & 4206 & 3571 & 6187 & 2654 & 357 & 302 & 2704 & 20320 \\
\hline 2012 & 153600 & 20194 & 5286 & 4339 & 7093 & 3002 & 358 & 356 & 3265 & 23459 \\
\hline 2013 & 170119 & 25846 & 6702 & 5689 & 8351 & 3666 & 534 & 437 & 3681 & 29527 \\
\hline 2014 & 194162 & 30914 & 7792 & 6798 & 10110 & 4541 & 664 & 496 & 4417 & 35331 \\
\hline 2015 & 212465 & 34810 & 8845 & 7100 & 11516 & 5253 & 900 & 550 & 4100 & 38910 \\
\hline
\end{tabular}

Source: Economic survey, 2010/11, 2012/13 \& Advisor Committee Report, 2015. 
Table 2: Elasticity and Buoyancy of Different Taxes (2000 to 2015)

\begin{tabular}{|l|c|c|c|}
\hline \multicolumn{1}{|c|}{ Items } & Buoyancy & Elasticity & Difference \\
\hline Total revenue & 1.33 & 0.66 & 0.67 \\
\hline Tax revenue & 1.47 & 0.64 & 0.83 \\
\hline Direct tax & 1.53 & 0.56 & 0.97 \\
\hline Indirect tax & 1.61 & 0.68 & 0.73 \\
\hline Income tax & 1.63 & 0.72 & 0.91 \\
\hline Custom duty & 1.23 & 0.63 & 0.91 \\
\hline VAT & 1.45 & 0.56 & 0.89 \\
\hline Excise duty & 1.71 & 0.72 & 0.99 \\
\hline Registration fee & 1.44 & 0.65 & 0.79 \\
\hline Vehicle tax & 1.63 & 0.66 & 0.97 \\
\hline Non tax & 0.87 & 0.43 & 0.44 \\
\hline
\end{tabular}

Source: Based on Table 1

The buoyancy coefficient of total revenue, tax revenue, direct tax, indirect tax, income tax revenue, custom duty, VAT, excise duty, registration fee, vehicle tax and non tax were observed to be 1.33,1.47,1.53,1.61 1.63, $1.23,1.45,1.71,1.44,1.63$, and 0.87 , respectively. These findings indicate that one percent change in GDP changed total revenue by 1.33 percent, tax revenue by 1.47 percent, indirect tax revenue by 1.61 percent, income tax by 1.63 percent, custom duty by 1.23 percent, VAT by 1.45 percent, excise duty by 1.71 percent, registration fee by 1.44 percent, vehicle tax by 1.63 percent, and nontax by 0.87 percent, respectively (Table 2). The buoyancy coefficients of all these taxes were greater than the elasticity coefficients which indicate that the discretionary changes could raise the additional revenue. Among the buoyancy coefficient of these taxes, the coefficient of excise duty was high, indicating that the discretionary actions could mobilize additional revenue from excise duty than others. And the government puts more emphasis on discretionary actions (especially on excise duty) rather than on broadening the excise base and on solving the problems of excise duty. 
The elasticity coefficient of total revenue, tax revenue, direct tax, indirect tax, income tax, custom duty, VAT, excise duty, registration fee, vehicle tax, nontax were found to be $0.66,0.64,0.56,0.68,0.72,0.63,0.56$, $0.72,0.65,0.66$, and 0.43 , respectively. The elasticity coefficients of the tax heads appeared less than unity. This shows that the tax system of Nepal as a whole could not be considered elastic and responsive to national income.

The elasticity coefficient of the total revenue was 0.66 for the study period. This result implies that the elasticity of the total revenue seemed 0.66. This indicates that one percent increase in gross domestic product (GDP) cause 0.66 percent increase (i.e., less than proportionately) in the total revenue component due to automatic response. Hence, it could be concluded that tax system of Nepal is not stabilized. As the buoyancy coefficient was 1.33 greater than unity, causing a discretionary effect of 0.67 , the tax system of Nepal was observed to rely heavily on the discretionary changes of the government. This result indicates that one percent change in GDP will change total revenue by 0.67 percent thanks to discretionary actions of the government. The discretionary effect of the tax revenue, direct tax, indirect tax, income tax revenue, custom duty, VAT, excise duty, registration fee, vehicle tax, and nontax in the study periods were $0.83,0.97,0.73,0.91$, $0.91,0.89,0.99,0.79,0.97$, and 0.44 respectively. These findings indicate that discretionary action of the government is seemed to be significantly increasing in the recent years to mobilize the resources through tax revenue in Nepal.

Indirect taxes were found to have considerably higher elasticity coefficient (0.68) than that of direct taxes (0.56) (Table 2). The buoyancy coefficient was significant at 1 percent level. However, the buoyancy coefficient for indirect taxes was greater than direct taxes. Because of a relatively small contribution of direct taxes on the one hand, and, more important because of not fully absorbing the increasing GDP to affect the level of direct taxes on the other. Nevertheless, all buoyancy coefficients for the whole period (2000 to 2015) were statistically significant at 1 percent level except in the case of nontax. 
Figure 1: Trends of Elasticity and Buoyancy of Different Taxes.

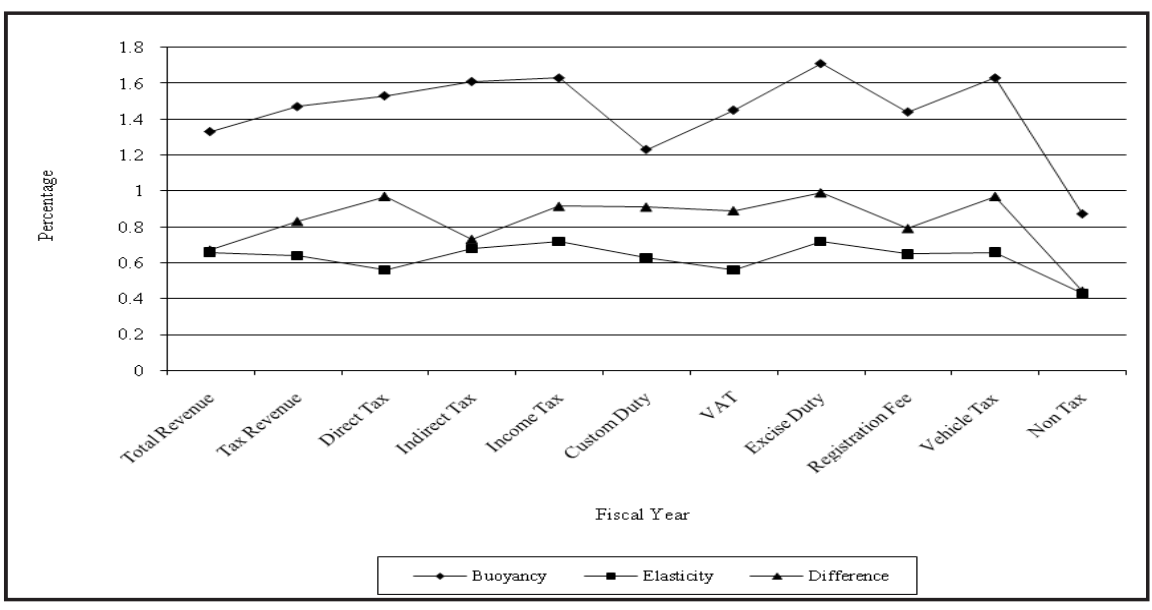

Forecasting of Various Taxes, 2018 to 2020

Table 3: Direct and Indirect Tax Forecasts (2018 to 2020)

(In Crores)

\begin{tabular}{|l|l|c|c|c|}
\hline Tax heads & \multicolumn{1}{|c|}{$\begin{array}{c}\text { Year } \\
\text { Total revenue }\end{array}$} & $\mathbf{2 0 1 8}$ & $\mathbf{2 0 1 9}$ & $\mathbf{2 0 2 0}$ \\
\hline Tax revenue & Forecasts & 55941 & 62029 & 68440 \\
\hline Direct tax & Forecasts & 15839 & 17936 & 20173 \\
\hline Income tax & Forecasts & 13572 & 15389 & 17329 \\
\hline Registration fee & Forecasts & 1368 & 1528 & 1697 \\
\hline Vehicle tax & Forecasts & 899 & 1019 & 1147 \\
\hline Indirect tax & Forecasts & 35543 & 39689 & 44075 \\
\hline Custom duty & Forecasts & 9911 & 10841 & 11818 \\
\hline VAT & Forecasts & 16956 & 18958 & 21061 \\
\hline Excise duty & Forecasts & 8676 & 9890 & 11195 \\
\hline Non tax & Forecasts & 5622 & 5999 & 6388 \\
\hline
\end{tabular}

Source: Based on Table $1 \& 2$. 
114 ANALYSIS OF ELASTICITY AND BUOYANCY AND PROJECTION ...

Figure 2: Trend of Forecasting the Direct Tax, Income Tax, Registration Fee, and Vehicle Tax (2018 to 2020).

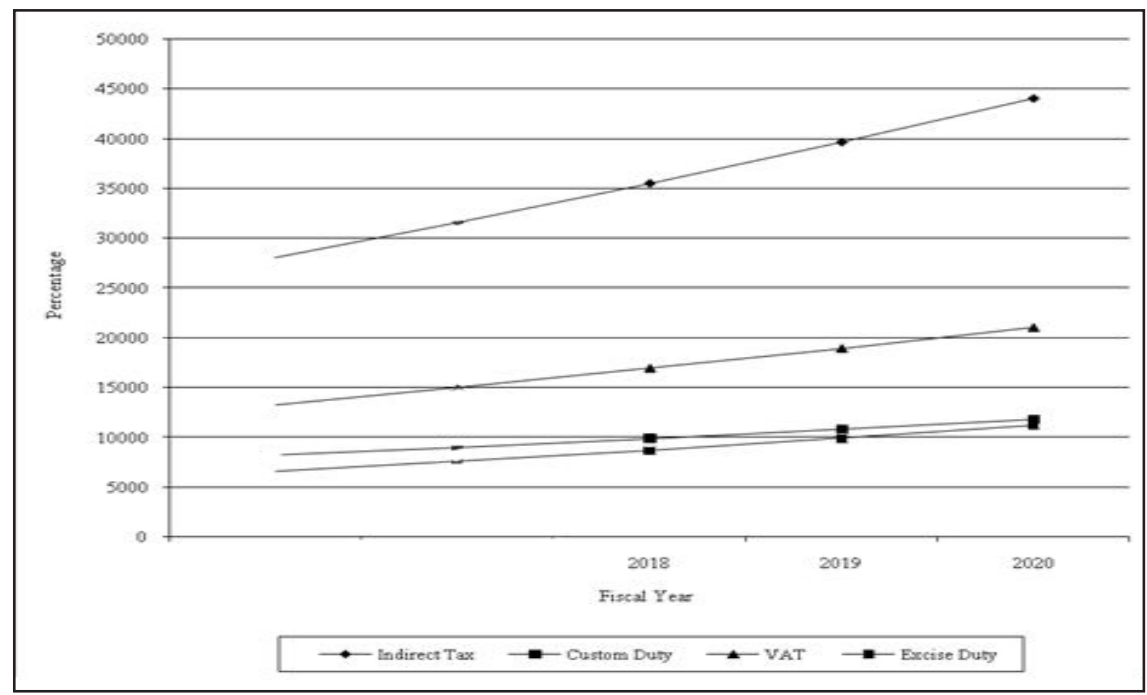

Figure 3: Trend of Forecasting the Indirect Tax, Custom Duties, VAT, and Excise Duties.

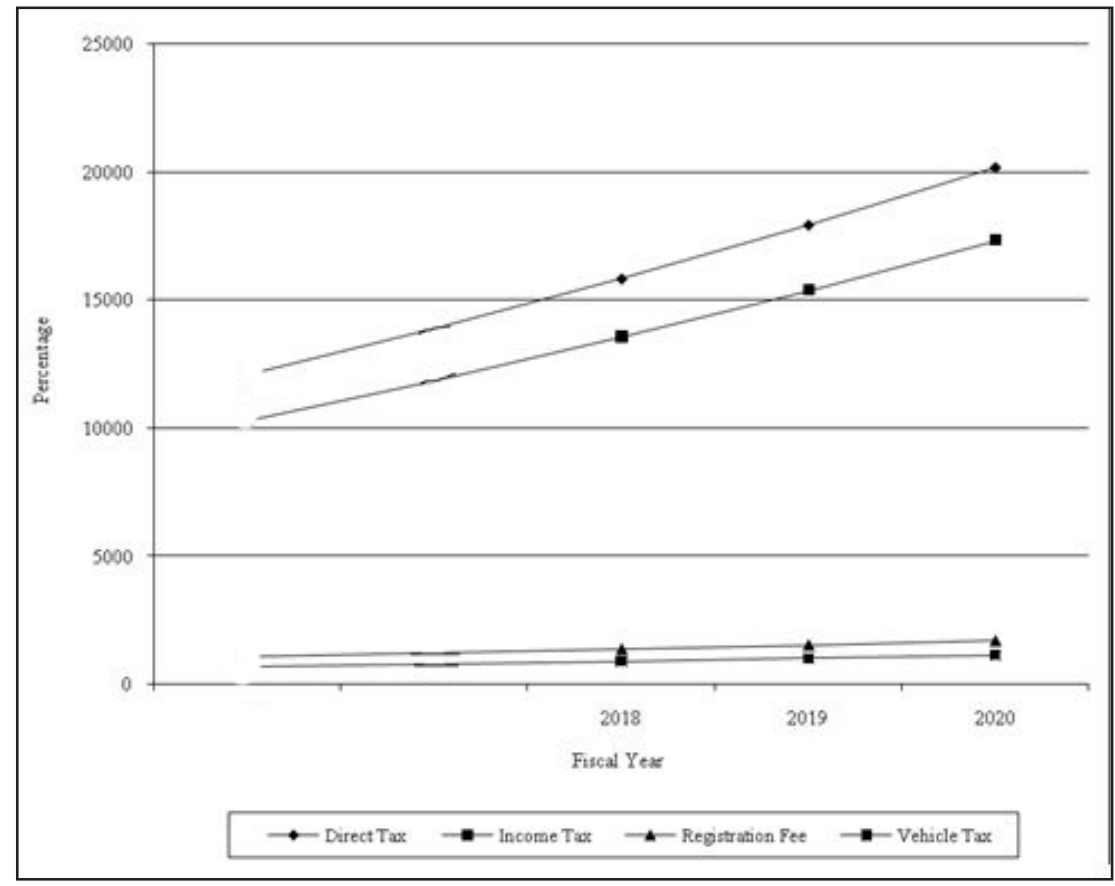


The projection of total revenue, tax revenue, direct tax, indirect tax, income tax, custom duty, VAT, excise duty, registration fee, vehicle tax, and nontax revenue from FY 2018 to FY 2020. It is projected that total revenue, direct tax, indirect tax, and nontax revenue will be Rs. 68440 crore, Rs. 20173 crore, Rs. 44075, and Rs. 6388 thr FY 2020, respectively. When we look at the data in Table 3, the ratio of indirect tax seems to be less than the direct tax. The increase in direct tax has been considered to be better for economic growth and also for tax equity. In developed countries, the ratio of direct tax and indirect tax seems equal (i.e., 50 percent). But their ratios in our country are 26.82 and 62.01 percent with total revenue in FY 2018. And the total revenue has been projected to be 29.48 and 64.40 percent in the FY 2020. This projection shows that we will not be able to meet the ratio of developed countries by FY 2020 (Table 3).

Similarly, income tax, VAT, custom and excise duties are projected to be Rs. 17329 crores, Rs. 21061 crores, Rs. 11818 crores and Rs. 11195 crores, by the FY 2020 respectively. These three are the major sources of revenue collection and resource mobilization in our country, and the projection made in the Table 3 could be taken positively. The above findings suggest that if we are able to reform these three taxes, this projection could be a green signal for revenue collection and resource mobilization. The finding of this study about elasticity and buoyancy is found to be consistent with the report of Revenue Advisory Committee (2015). In other words, the findings of the trends of elasticity and buoyancy analysis of different tax structures, including forecasts over the year 2018 to 2020 are in line with the findings of the report of Revenue Advisory Committee.

\section{CONCLUSION}

While projecting the tax, the Buoyancy and Elasticity coefficient between the GDP and different headings of revenue (VAT), Income tax, Custom duty, Excise duty, Registration fee, and Vehicle tax of the last fifteen years has been calculated. The results recorded in Table 1 and 2 show that the overall-tax system of Nepal appears to be inelastic in nature during study periods. Moreover, direct taxes seems to have smaller elasticities in comparison with indirect taxes, which indicates that direct taxes were responsible for the sluggishness of tax yields. Buoyancy coefficients of major taxes turn out to be much higher than their respective elasticities, and these findings provide greater implications for the high discretionary effects of the government to have more revenue. 


\section{REFERENCES}

Agrawal, G. R. (1998). Resource mobilization in Nepal. Kathmandu: Center for Economic Development and Administration.

Chapagain, N. (2003). A study on tax structure of Nepal: Elasticity and buoyancy measurement. An unpublished master's thesis. Patan Multiple Campus, Patandhok: TU.

Dahal, M. K. (1983). Taxation in Nepal: A study of its structure, productivity and burden. An unpublished doctoral dissertation. India:University of Bombay.

Dhaungana, B. (1980). Financial resource mobilization in Nepal during the ninenteen eightees. Kathmandu: Center for Economic Development and Administration.

Gautam, S.S. (2008). Resource mobilization through income tax in Nepal. An unpublished Master's Thesis, Central Department of Economics, TU.

Mansfield, C. Y. (1972). Elasticity and buoyancy of a tax system: A method applied to Paraguay. IMF Staff Papers, 19.

Rana, A. S. (2008). An analysis of tax structure and responsiveness of tax yields in Nepal. An unpublished doctoral dissertation, Central Department of Economics, TU.

Sahota, G.S. (1961). Indian tax structure and economic development. Bombay, India: Asia Publishing House. 